\title{
EFFECTS OF CADMIUM AND LEAD CONCENTRATIONS AND ARBUSCULAR MYCORRHIZA ON GROWTH, FLOWERING AND HEAVY METAL ACCUMULATION IN SCARLET SAGE (SALVIA SPLENDENS SELLO 'TORREADOR')
}

\author{
Joanna Nowak \\ Department of Floriculture, Research Institute of Pomology and Floriculture Pomologiczna 18, 96100 Skierniewice, Poland \\ e mail: Joanna.Nowak@insad.pl
}

Received: 20.03.2007

\section{S u m m a r y}

The objective of this research was to examine the influ ence of $\mathrm{Cd}\left(0,10,20,40 \mathrm{mg} \mathrm{Cd} \cdot \mathrm{dm}^{3}\right)$ and $\mathrm{Pb}(0,10,100,200$ $\left.\mathrm{mg} \mathrm{Pb} \cdot \mathrm{dm}^{3}\right)$ in growing substrate and mycorrhizal colonization of root system on growth, flowering, $\mathrm{Cd}$ and $\mathrm{Pb}$ accumulation in scarlet sage shoots. Both $\mathrm{Cd}$ and $\mathrm{Pb}$ had a negative effect on my corrhizal colonization of scarlet sage roots. The effect of $\mathrm{Cd}$ and $\mathrm{Pb}$ on the growth of scarlet sage was negligible. $\mathrm{Cd}$ at $40 \mathrm{mg} \cdot \mathrm{dm}^{3}$ lowered the number of inflorescences and caused slight chloro sis of the lowermost leaves. $\mathrm{Pb}$ at $200 \mathrm{mg} \cdot \mathrm{dm}^{3}$ caused drying of the lowermost leaves. Both heavy metals accelerated flowering of non mycorrhizal plants, independently of the concentration in growing media. $\mathrm{Cd}$ and $\mathrm{Pb}$ contents in scarlet sage shoots incre ased with the increasing content of these heavy metals in growing substrate in both non mycorrhizal and mycorrhizal plants. My corrhization decreased the growth of scarlet sage and increased the accumulation of $\mathrm{Cd}$ and $\mathrm{Pb}$ in shoots of plants grown in media strongly polluted with heavy metals.

Key words: Salvia splendens, mycorrhization, heavy metals, growth, flowering

\section{INTRODUCTION}

The heavy metals content in urban soils is very often above legally allowable limits (Diattaet al. 2003). Heavy metal pollution of soil enhances plant uptake causing accumulation in plant tissues, growth inhibition and visible phytotoxicity in urban vegetation. The identification and selection of ornamental plant species that possess the ability to accumulate metals and to grow vigorously in contaminated soils can increase the ornamental value of urban vegetation and allow them to be used for phytoremediation.

$\mathrm{Cd}$ and $\mathrm{Pb}$ are nonessential elements toxic to plants and animals. Significant differences in plant ability to accumulate heavy metals and in plant responses to heavy metal toxicity have been observed (B egonia, 1997; Vassilev et al. 2004). Some plants, so called hyperaccumulators, can absorb relatively high heavy metal concentrations and translocate them to the harvestable shoots where they accumulate. Such plants could be used to remove heavy metals from contaminated soils. We is s enhorn et. al. (1995) showed that AMF colonization of root system could either reduce or increase the heavy metal content of plants, depending on growth conditions, the fungus and the metal.

The objective of the study was to investigate the influence of $\mathrm{Cd}$ and $\mathrm{Pb}$ concentrations in growing substrate and AMF colonization of root system on growth, flowering, and $\mathrm{Cd}$ and $\mathrm{Pb}$ accumulation in scarlet sage which, as a bedding plant, can be used for phytoextraction of heavy metals in urban areas.

\section{MATERIAL AND METHODS}

Seeds of scarlet sage (Salvia splendens Sello cv. Torreador) were used for the experiments. The seeds were sown in the middle of February and the seedlings were then planted at the beginning of March into Klasmann KTS 3 substrate ( $\mathrm{pH}$ 6.0, total soluble salts $\left.0.68 \mathrm{~g} \mathrm{KCl}^{-3} \mathrm{dm}^{-3}\right)$. The substrate was inoculated with Endorize-TA AMF inoculum, containing a mixture of different Glomus species, mainly Glomus intraradices (Biorize Sarl, France), as described earlier (Nowak, 2004). The substrate was not sterilized. The Klasmann substrate used in this experiment was devoid of AM fungi, as confirmed by the absence of colonization in the non-inoculated treatments. The percentage of root colonization by AM fungi was estimated as described by Philips and Hay man (1970). Pots were arranged on greenhouse benches in a randomized complete bock 
design with four replicates per treatment, using 5 plants as a replicate.

One month after planting, the plants were given $200 \mathrm{ml}$ of solution containing: $0,10,20$, and $40 \mathrm{mg}$ $\mathrm{Cd} \cdot \mathrm{dm}^{-3}$ substrate, or $0,10,100$, and $200 \mathrm{mg} \mathrm{Pb} \cdot \mathrm{dm}^{-3}$ substrate. $\mathrm{Cd}$ was applied as $\mathrm{Cd}\left(\mathrm{NO}_{3}\right)_{2} \cdot 4 \mathrm{H}_{2} \mathrm{O}, \mathrm{Pb}$ was applied as $\mathrm{Pb}\left(\mathrm{NO}_{3}\right)_{2}$. Different amounts of nitrogen were compensated with respective amounts of $\mathrm{NH}_{4}\left(\mathrm{NO}_{3}\right)_{2}$. The plants were exposed to heavy metals treatment for 8 weeks.

The plants were cultivated under glass to the end of June. The greenhouse was maintained at $16^{\circ} \mathrm{C}$ during the night and ventilated when the temperature reached $24^{\circ} \mathrm{C}$ during the day. The plants were fertilized with the commercial fertilizer Symfovita A $(12.5 \mathrm{~N}-2.1 \mathrm{P}-18.5$ $\mathrm{K}-2.9 \mathrm{Mg}-0.025 \mathrm{~B}-0.025 \mathrm{Zn}-0.0005 \mathrm{Co}-0.1 \mathrm{Mn}$ - $0.02 \mathrm{Cu}-0.003 \mathrm{Mo}$ ) at a concentration of $1 \mathrm{~g} \cdot \mathrm{dm}^{-3}$ twice a week.

All measurements were conducted at the end of the experiments. Dry weight of shoots and roots, plant height, number of days from planting to flowering, flower number, and colonization of root system by AM fungi were determined.

For $\mathrm{Cd}$ and $\mathrm{Pb}$ determination, the shoots were oven-dried to constant weight at $78^{\circ} \mathrm{C}$, milled to homogeneous samples, and then treated with $\mathrm{HNO}_{3}$ at $180^{\circ} \mathrm{C}$, pressure $20 \mathrm{~atm}$. for $40 \mathrm{~min}$. (microwave oven Mars-5, Candela, USA). The concentrations of $\mathrm{Cd}$ and $\mathrm{Pb}$ were measured spectrophotometrically by using ICP (OPTIMA 2000 DV, Perkin-Elmer, USA).

The treatments were statistically analyzed by analysis of variance and means were compared with Duncan's multiple range test at $95 \%$ level of significance.

\section{RESULTS AND DISCUSSION}

Mycorrhiza was not observed in the root system of the non-inoculated scarlet sage plants. Roots of the inoculated plants were colonized by AM fungi (Tab. 1). The addition of $\mathrm{Cd}$ and $\mathrm{Pb}$ to the growth substrate decreased root colonization by AMF. Mycorrhizal colonization was earlier shown to be delayed, reduced or even eliminated by high concentrations of heavy metals (Gildon and Tinker, 1983; Koul et al. 2001). No effect of high Cd concentration on AMF colonization of root system was observed by $\mathrm{Ch}$ en et al. 2003. Differences in tolerance to Cd concentration in soils between different Glomus species were also noted ( $\mathrm{L}$ i a o et al. 2003).

Mycorrhizal plants had lower dry weight of shoots than those of the non-inoculated ones (Tab. 2 and 3). Mycorrhization also decreased plant height and inflorescence number. The effect of mycorrhization on shoot number was negligible. Mycorrhization did not affect flowering time of scarlet sage cultivated in the growing medium not contaminated with $\mathrm{Cd}$, and slightly delayed flowering of plants cultivated in $\mathrm{Cd}$ and $\mathrm{Pb}$ polluted media.
Table 1

The effect of $\mathrm{Cd}$ and $\mathrm{Pb}$ concentrations in growing medium on percentage of scarlet sage (Salvia splendens Sello 'Torreador') root colonization by AMF.

\begin{tabular}{|c|c|c|c|}
\hline $\begin{array}{c}\mathrm{Cd} \\
\text { concentration } \\
\left(\mathrm{mg} \mathrm{Cd} \cdot \mathrm{dm}^{3}\right)\end{array}$ & $\begin{array}{l}\text { Percentage of } \\
\text { root coloni } \\
\text { zation }\end{array}$ & $\begin{array}{c}\mathrm{Pb} \\
\text { concentration } \\
\left(\mathrm{mg} \mathrm{Pb} \cdot \mathrm{dm}^{3}\right)\end{array}$ & $\begin{array}{l}\text { Percentage of } \\
\text { root coloni } \\
\text { zation }\end{array}$ \\
\hline 0 & $40 \mathrm{c}$ & 0 & $40 \mathrm{c}$ \\
\hline 10 & $27 b$ & 10 & $33 \mathrm{bc}$ \\
\hline 20 & $23 a$ & 100 & $30 \mathrm{~b}$ \\
\hline 40 & $23 a$ & 200 & $20 \mathrm{a}$ \\
\hline
\end{tabular}

Means within columns followed by the same letter(s) are not significantly different at $\alpha 0.05$

It is well know that in the conditions of mineral nutrient availability mycorrhization can depress root and shoot growth primarily by sink competition for photosynthates (D o u d s et al. 1988), while in nutrient-poor growing substrates mycorrhizal plants have more access to mineral nutrients due to the external hyphae development and they affect positively plant growth. In this experiment, all the plants were fertilized with a complete nutrient solution. In field cultivation, mycorrhizal roots can explore more soil volume than non-mycorrhizal ones, due to their extramatrical hyphae development (S awaki and Saito, 2001). Results obtained by Dunh a m et al. (2003) also suggest that under greenhouse conditions AMF act to reduce plant growth despite increased mineral nutrition and photosynthetic activity. The effect of mycorrhization on Cd tolerance could be also less pronounced in pot culture than in field conditions.

Dry weight of shoots was unaffected by $\mathrm{Cd}$ concentration in the growing medium in both the non-inoculated and inoculated plants (tab. 2), although the lowermost leaves of the plants grown under the highest $\mathrm{Cd}$ concentration were slightly chlorotic. Higher $\mathrm{Cd}$ concentration in growing media accelerated flowering of the non-mycorrhizal plants and did not affect flowering time of the AMF inoculated plants. Higher $\mathrm{Cd}$ concentration in growing media slightly decreased the number of inflorescences. The inhibition of growth due to $\mathrm{Cd}$ pollution was frequently observed in other plants (Rivera-Becerril et al. 2002; Vassilev et al. 2004). Cadmium, if not detoxified rapidly in plant tissue, may induce oxidative stress leading to growth inhibition and finally cell death (Schutzendubel and Polle, 2002).

$\mathrm{Pb}$ concentration had no significant effect on growth of scarlet sage but slightly accelerated flowering time in the non-inoculated plants. One month after tre- 
Table 2

The effect of cadmium concentration in growing medium and mycorrhizal inoculation on growth and flowering of scarlet sage (Salvia splendens Sello 'Torreador').

\begin{tabular}{|c|c|c|c|c|c|c|}
\hline \multicolumn{2}{|c|}{ Treatments } & \multirow[b]{2}{*}{$\begin{array}{c}\text { DW of shoots } \\
\text { (g) }\end{array}$} & \multirow[b]{2}{*}{$\begin{array}{l}\text { Height of plant } \\
(\mathrm{cm})\end{array}$} & \multirow[b]{2}{*}{$\begin{array}{c}\text { Number of } \\
\text { shoots }\end{array}$} & \multirow{2}{*}{$\begin{array}{c}\text { Number of } \\
\text { days from } \\
\text { planting to } \\
\text { flowering }\end{array}$} & \multirow[b]{2}{*}{$\begin{array}{c}\text { Number of } \\
\text { infloresc. }\end{array}$} \\
\hline $\begin{array}{c}\mathrm{Cd} \\
\text { concentr. } \\
\left(\mathrm{mg} \mathrm{Cd} \cdot \mathrm{dm}^{3}\right)\end{array}$ & $\begin{array}{l}\text { AMF } \\
\text { inocul. }\end{array}$ & & & & & \\
\hline $\begin{array}{c}0 \\
10 \\
20 \\
40\end{array}$ & $\begin{array}{l}+ \\
+ \\
\end{array}$ & $\begin{array}{c}7.5 \mathrm{c} \\
5.5 \mathrm{a} \\
6.9 \mathrm{bc} \\
5.5 \mathrm{a} \\
6.7 \mathrm{~b} \\
5.7 \mathrm{a} \\
7.0 \mathrm{bc} \\
5.9 \mathrm{a} \\
\end{array}$ & $\begin{array}{c}34.9 \mathrm{c} \\
29.8 \mathrm{ab} \\
34.3 \mathrm{c} \\
28.8 \mathrm{a} \\
32.9 \mathrm{c} \\
29.8 \mathrm{ab} \\
32.3 \mathrm{bc} \\
28.9 \mathrm{a} \\
\end{array}$ & $\begin{array}{c}4.9 \mathrm{~b} \\
4.6 \mathrm{~b} \\
4.0 \mathrm{ab} \\
3.1 \mathrm{a} \\
4.9 \mathrm{~b} \\
3.3 \mathrm{a} \\
4.9 \mathrm{~b} \\
4.2 \mathrm{ab} \\
\end{array}$ & $\begin{array}{l}31.8 \mathrm{~b} \\
31.3 \mathrm{~b} \\
27.6 \mathrm{a} \\
31.3 \mathrm{~b} \\
27.3 \mathrm{a} \\
31.4 \mathrm{~b} \\
27.7 \mathrm{a} \\
32.6 \mathrm{~b} \\
\end{array}$ & $\begin{array}{c}7.0 \mathrm{~d} \\
5.4 \mathrm{ab} \\
5.7 \mathrm{bc} \\
3.7 \mathrm{a} \\
6.2 \mathrm{~cd} \\
4.6 \mathrm{ab} \\
5.9 \mathrm{bc} \\
4.0 \mathrm{a} \\
\end{array}$ \\
\hline $\begin{array}{l}\text { Significance } \\
\text { Cd concentration } \\
\text { Mycorrhization } \\
\text { Cd x Mycorrhiz. }\end{array}$ & & $\begin{array}{c}\mathrm{ns} \\
\mathrm{xxx} \\
\mathrm{ns}\end{array}$ & $\begin{array}{c}\mathrm{ns} \\
\mathrm{xxx} \\
\mathrm{ns}\end{array}$ & $\begin{array}{l}\mathrm{xx} \\
\mathrm{xx} \\
\mathrm{ns}\end{array}$ & $\begin{array}{c}\mathrm{xxx} \\
\mathrm{xxx} \\
\mathrm{xx}\end{array}$ & $\begin{array}{c}\mathrm{xx} \\
\mathrm{xxx} \\
\mathrm{x}\end{array}$ \\
\hline
\end{tabular}

The means in columns followed by the same letter(s) do not differ at $\alpha \quad 0.05 ; \mathrm{ns}$., $\mathrm{x}, \mathrm{xx}, \mathrm{xxx}$ non significant or significant at $\alpha \quad 0.1,0.05,0.001$, respectively; non mycorrhizal plants, + mycorrhizal plants.

Table 3

The effect of lead concentration in growing medium and mycorrhizal inoculation on growth and flowering of scarlet sage (Salvia splendens Sello 'Torreador').

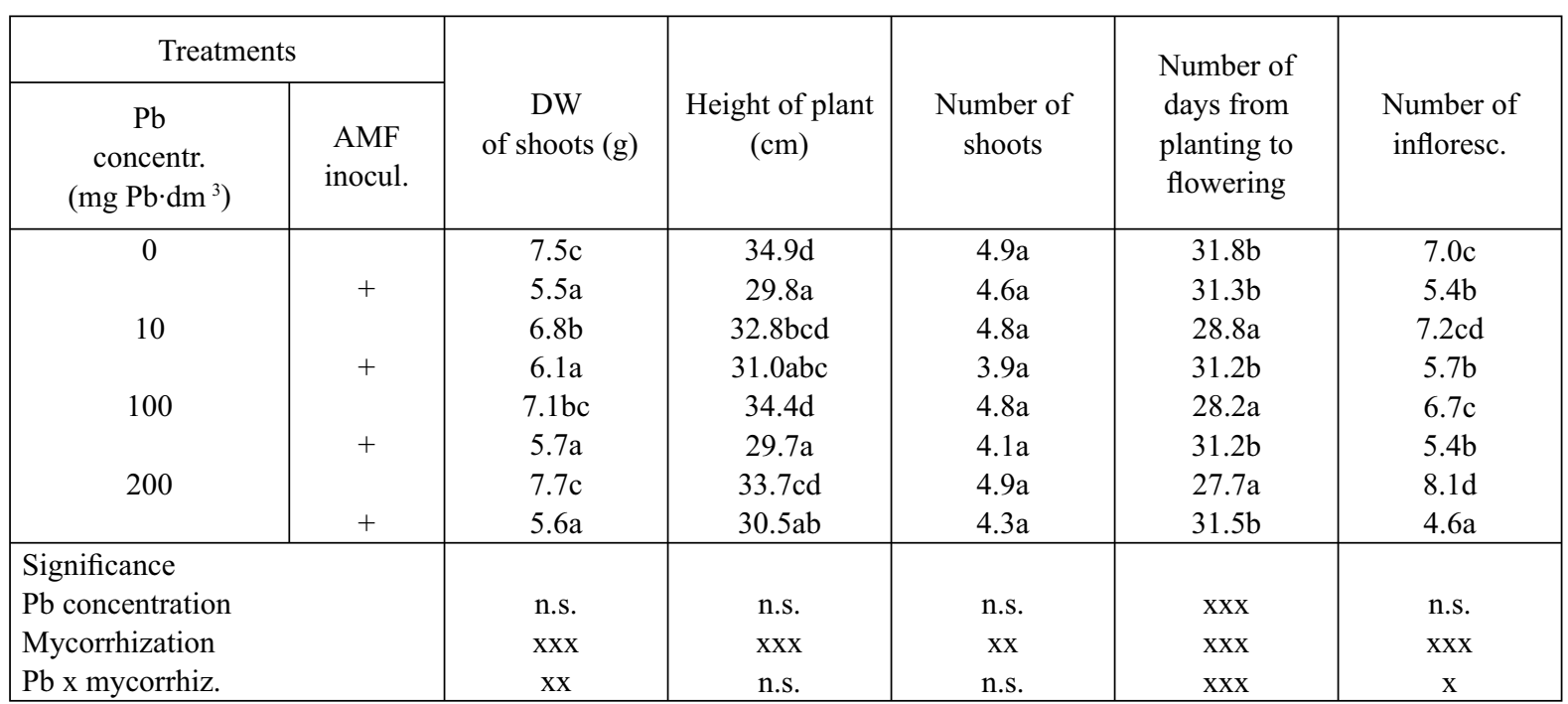

Explanations as in Table 2.

atment with $\mathrm{Pb}$, chlorotic spots were observed on the lowermost leaves of the non-inoculated and inoculated scarlet sage plants grown at $200 \mathrm{mg} \mathrm{Pb} \cdot \mathrm{dm}^{-3}$. Later on, the lowermost leaves became dry. It is well known that phytotoxicity of $\mathrm{Pb}$ is relatively low. $\mathrm{Pb}$ accumulates in the largest leaves, its transport to younger leaves is inhibited (Cseh et al. 2000). Stunting is a commonly observed growth response in a wide range of plants grown in metal polluted soils (F oy et al. 1978). Stunting, reduced biomass and chlorosis of $\mathrm{Pb}$-treated plants can be due to the inhibition of chlorophyll synthesis and decline in the photosynthetic rate, a specific toxicity of the metal to the plant, antagonism with other nutrients or the inhibition of root penetration in the soil ( $\mathrm{Sh}$ a r m a and Dubey, 2005). In this experiment, the effect of $\mathrm{Pb}$ on growth and flowering of scarlet sage was negligible, probably due to low sensitivity to $\mathrm{Pb}$ pollution. The differential growth response of various species to $\mathrm{Pb}$ was earlier observed by B e g o n i a (1997). These differences suggest that the phytotoxic mechanism of $\mathrm{Pb}$ involve different biochemical pathways in different plant species.

Heavy metals uptake by plants depends on both soil and plant factors (Gleba et al. 1990). The main soil factor affecting heavy metals uptake by plants is 
Table 4

The effect of lead concentration in growing medium and AMF inoculation on $\mathrm{Pb}$ content in shoots of scarlet sage (Salvia splendens Sello 'Torreador').

\begin{tabular}{|c|c|c|c|c|c|}
\hline $\begin{array}{c}\mathrm{Cd} \\
\text { concentration } \\
\left(\mathrm{mg} \mathrm{Cd} \cdot \mathrm{dm}^{3}\right)\end{array}$ & AMF inocul. & $\begin{array}{l}\text { Cd content of shoots } \\
\left(\mathrm{mg} \cdot \mathrm{kg}^{1} \mathrm{DW}\right)\end{array}$ & $\begin{array}{c}\mathrm{Pb} \\
\text { concentration } \\
\left(\mathrm{mg} \mathrm{Pb} \cdot \mathrm{dm}^{3}\right)\end{array}$ & AMF inocul. & $\begin{array}{c}\mathrm{Pb} \text { content of shoots } \\
\left(\mathrm{mg} \cdot \mathrm{kg}^{1} \mathrm{DW}\right)\end{array}$ \\
\hline $\begin{array}{c}0 \\
10 \\
20 \\
40\end{array}$ & $\begin{array}{l}+ \\
+ \\
+ \\
+ \\
+\end{array}$ & $\begin{array}{c}0.86 \mathrm{a} \\
0.75 \mathrm{a} \\
8.81 \mathrm{~b} \\
12.55 \mathrm{~b} \\
20.4 \mathrm{c} \\
24.5 \mathrm{c} \\
38.65 \mathrm{~d} \\
50.10 \mathrm{e}\end{array}$ & $\begin{array}{c}0 \\
10 \\
100 \\
200\end{array}$ & $\begin{array}{l}+ \\
+ \\
+ \\
+ \\
+\end{array}$ & $\begin{array}{c}34.7 \mathrm{a} \\
31.2 \mathrm{a} \\
22.7 \mathrm{a} \\
20.0 \mathrm{a} \\
189.0 \mathrm{~b} \\
282.0 \mathrm{c} \\
147.5 \mathrm{~b} \\
330.0 \mathrm{c}\end{array}$ \\
\hline $\begin{array}{l}\text { Significance } \\
\mathrm{Pb} \text { concentration } \\
\text { Mycorrhization } \\
\mathrm{Pb} \mathrm{x} \text { mycorrhiz. }\end{array}$ & & $\begin{array}{c}\mathrm{xxx} \\
\mathrm{xx} \\
\mathrm{xx}\end{array}$ & $\begin{array}{l}\text { Significance } \\
\mathrm{Pb} \text { concentration } \\
\text { Mycorrhization } \\
\mathrm{Pb} \text { x mycorrhiz. }\end{array}$ & & $\begin{array}{c}\mathrm{xxx} \\
\mathrm{xx} \\
\mathrm{xxx}\end{array}$ \\
\hline
\end{tabular}

Explanations as in Table 2.

soil heavy metal content. Among the plant factors affecting heavy metal uptake, plant genotype is considered the most important. Some plants have an exceptional capacity to accumulate $\mathrm{Cd}$ in high $\mathrm{Cd}$ exposure without any toxicity symptoms, great differences in $\mathrm{Cd}$ accumulation due to species and cultivars were also suggested (Ts adilas, 2000; Angelova et al. 2004). Cadmium and lead concentrations in scarlet sage shoots are shown in Table 4. Cd accumulation in scarlet sage shoots was dependent on $\mathrm{Cd}$ concentration in growing media. With the increased $\mathrm{Cd}$ doses, $\mathrm{Cd}$ content of the shoots increased as well, in both the non-mycorrhizal and mycorrhizal plants, although in the highest $\mathrm{Cd}$ exposure the mycorrhizal plants took up more $\mathrm{Cd}$ than the non-mycorrhizal ones. The ability of AM fungus hyphae to acquire and translocate $\mathrm{Cd}$ was earlier confirmed using separated zones for hyphae and roots (Guo et. al. 1996).

Low levels of $\mathrm{Pb}$ accumulated in shoots of the plants growing in the absence of added $\mathrm{Pb}$ (Tab. 4). $\mathrm{Pb}$ accumulation in shoots of scarlet sage increased greatly with the increasing $\mathrm{Pb}$ concentration in the growing medium. Earlier results showed that different plant species exhibit differential ability to take up $\mathrm{Pb}$ and to transport and accumulate it in shoots (B e g o nia, 1997). Mycorrhization increased $\mathrm{Pb}$ accumulation in shoots of scarlet sage grown at 100 and $200 \mathrm{mg} \mathrm{Pb} \cdot \mathrm{dm}^{-3}$. Increased accumulation of $\mathrm{Pb}$ in shoots of AMF inoculated red kidney and wheat plants was noted by Rabie (2005). The higher metal concentration in the AMF inoculated plants could be explained by the fact that inoculation enlarges the absorbing area and efficient hyphal translocation.

\section{CONCLUSIONS}

1. The effect of $\mathrm{Cd}$ and $\mathrm{Pb}$ on growth and flowering of scarlet sage was negligible, but heavy metal pollution lowered the decorative value of plants due to chlorosis and necrosis of leaves.

2. Accumulation of $\mathrm{Cd}$ and $\mathrm{Pb}$ in scarlet sage shoots is dependent on metals content in the growing medium.

3. Mycorrhization increased $\mathrm{Cd}$ and $\mathrm{Pb}$ accumulation in shoots of scarlet sage grown at high concentrations of these metals in the growing medium.

\section{REFERENCES}

A n g e lova V., I va nov K., I v a n o va R. 2004. Effects of chemical forms of lead, cadmium, and zinc in polluted soils on their uptake by tobacco. Journal of Plant Nutri tion, 27(5): 757773.

B e g o n i a G. B. 1997. Comparative lead uptake and response of some plants grown on lead contaminated soils. J. Mis sisipi Acad. Sci. 42(2): 101106.

Ch en B. D., Li u Y., S h en H., Li X. L., C h risti e P. 2003. Uptake of cadmium from an experimentally conta minated calcareous soil by arbuscular mycorrhizal maize (Zea mays L.). Mycorrhiza, 14(6): 347354.

C s e h E., F o d o r F., V a r g a A., Z a r a y G. 2000. Effect of lead treatment on the distribution of essential elements in cucumber. Journal of Plant Nutrition, 23(8): 10951105.

D i a t t a J. B., Grze bi s z W., A p o lin arsk a K. (2003). A study of soil pollution by heavy metals in the city of Poznań (Poland) using dandelion (Taraxacum officinale WEB) as a bioindicator. Electronic Journal of Polish Agricultural Universities, 6(2). 
D u n h a m R. M., R a y A. M., I n o u y e R. S. 2003. Growth, physiology, and chemistry of mycorrhizal and nonmycorr hizal Typha latifolia seedlings. Wetlands, 23 (4): 890896.

D o u d s jr D. D., J o h n s o n C.R., K o c h K.E. 1988. Carbon cost of the fungal symbiont relative to net leaf $\mathrm{P}$ accu mulation in a split root VA mycorrhizal symbiosis. Plant Physiol. 86: 491496.

F o y C. D., Ch a n e y R. L., W h it e M. C. 1978. The physiol ogy of metal toxicity in plants. Ann. Rev Plant Physiol. 29: 511566.

G i $1 \mathrm{~d}$ o $\mathrm{n}$ A., T i n k e r P. B. 1983. Interactions of vesicu lar arbuscular mycorrhizal infection and heavy metals in plants. New Phytol. 95: 247261.

G l eb a D., B oris i uk N. V., B oris iuk L. G., Kne er R., Pou 1 e v A., Skarzhinskay a M., Dushenkov S., L o g e n d r a S., G 1 e b a Y. Y., R a s k i n I. 1999. Use of plant roots for phytoremediation and molecular farming. Proc. Natl. Acad. Sci. USA, 96: 59735977.

G u o Y., G e or g e E., M a r s c h n e r H. 1996. Contribu tion of an arbuscular mycorrhizal fungus to the uptake of cadmium and nickel in bean and maize plants. Plant Soil. 184: 195205.

K o u 1 M., K a p o o r R., L u i $\mathrm{k}$ h a m N. 2001. Influence of lead in soil on mycorrhizal development and plant growth of Cyamopsis tetragonoloba (Linn.) Taub. Indian J. Exp. Biol. 39(5): 459463.

L i a o J. P., L i n X. G., C a o Z.H., S h i Y.Q., W o n g M. H. 2003. Interactions between arbuscular mycorrhizae and heavy metals under sand culture experiment. Chemo sphere, 50(6): 847853.

$\mathrm{N}$ o w a k J. 2004. Effects of arbuscular mycorrhizal fungi and organic fertilization on growth, flowering, nutrient upta ke, photosynthesis and transpiration of geranium (Pelargonium hortorum L.H. Bailey 'Tango Orange'). Symbio sis, 37: 259266

P h $i 11$ i p s J. M., H a y m a n D. S. 1970. Improved procedures for clearing roots and staining parasitic and vesicular ar buscular mycorrhizal fungi for rapid assessment of infec tion. Transactions of the British Mycological Society, 55: 150160 .

Rabie G. H. 2005. Contribution of arbuscular mycorrhizal fun gus to red kidney and wheat plants tolerance grown in heavy metal polluted soil. African Journal of Biotechno logy. 4(4): 332345.

Rivera Berceril F., Calantzis C., Turnau K., Caus sanel J.P., Belimov A. A., Gianinazz iS., Stras ser R. J., Gianinazzi Pearson V.2002. Cadmium accumulation and buffering of cadmium induced stress by arbuscular mycorriza in three Pisum sativum $L$. geno types. Journal of Experimental Botany, 53(37): 1117 1185.

Sawaki H., Saito M. 2001. Expressed genes in the extraradi cal hyphae of an arbuscular mycorrhizal fungus, Glomus intraradices, in the symbiotic phase. FEMS Microbiol ogy Letters, 195: 109113.
Schutzendubel A., Polle A., 2002. Plant responses to abiotic stresses: heavy metal induced oxidative stress and pro tection by mycorrization. Journal of Experimental Biology, 53(372): 13511365.

Sharma P., Dubey R. S. 2005. Lead toxicity in plants. Brazi lian Journal of Plant Physiology, 17 (1): 126.

Tsadilas C. D. 2000. Soil pH influence on cadmium uptake by tobacco in high cadmium exposure. Journal of Plant Nutrition, 23(8): 11671178.

Vassilev A., Lindon F. C., Ramalho J. C., Do Ceu Ma to s M., B areiro M. G. 2004. Shoot cadmium accumu lation and photosynthetic performance of barley plants exposed to high cadmium treatments. Journal of Plant Nutrition, 27(3): 775795.

Weissenhorn I., Leyval C., B elgy G., Berthelin J. 1995. Arbuscular mycorrhizal contribution to heavy metal upta ke by maize (Zea mays L.) in pot culture with contamina ted soil. Mycorrhizae, 5: 245251.

\section{Acknowledgment}

This research was supported by a grant No 3 P06R 04224 from Polish State Committee for Scientific Research.

\section{Wpływ stężeń kadmu i ołowiu oraz mikoryzacji na wzrost, kwitnienie i akumulację metali ciężkich w szałwii lśniącej (Salvia splendens Sello 'Torreador')}

\section{Streszczenie}

Badania miały na celu określenie wpływu zawartości kadmu $\left(0,10,20,40 \mathrm{mg} \mathrm{Cd} \cdot \mathrm{dm}^{-3}\right)$ i ołowiu $\left(0,10,100,200 \mathrm{mg} \mathrm{Pb} \cdot \mathrm{dm}^{-3}\right)$ w podłożu oraz mikoryzy arbuskularnej na wzrost, kwitnienie i akumulacje $\mathrm{Cd}$ i $\mathrm{Pb}$ w pędach szałwii lśniącej. Zarówno $\mathrm{Cd}$ jak i $\mathrm{Pb}$ wpływały ujemnie na kolonizację korzeni przez grzyby tworzące mikoryzę arbuskularną. Wpływ obu metali ciężkich na wzrost szałwii był niewielki. Cd w stężeniu $40 \mathrm{mg} \cdot \mathrm{dm}^{-3}$ obniżał liczbę kwiatostanów i powodował lekka chloroze liści dolnych, a $\mathrm{Pb}$ w stężeniu $200 \mathrm{mg} \cdot \mathrm{dm}^{-3}$ zasychanie liści dolnych. Oba metale ciężkie przyspieszały kwitnienie roślin nie poddanych mikoryzacji, niezależnie od stężenia w podłożu. Zawartości $\mathrm{Cd}$ i $\mathrm{Pb}$ w pędach szałwii lśniącej wzrastały wraz ze wzrostem zawartości tych pierwiastków w podłożu, zarówno u roślin nie zmikoryzowanych jak i zmikoryzowanych. Mikoryzacja wpływała ujemnie na wzrost szałwii oraz zwiększała akumulację $\mathrm{Cd}$ i $\mathrm{Pb}$ w pędach roślin rosnących w podłożach silnie zanieczyszczonych tymi pierwiastkami. 
